\title{
Juri Apresjan and the Development of Semantics and Lexicography
}

Igor Burkhanov, Section of Applied Linguistics, Institute of English Studies, University of Rzeszów, Rzeszów, Poland (burkhan@univ.rzeszow.pl)

\begin{abstract}
The major aim of this article is to highlight Juri Apresjan's impact on the development of linguistic semantics and theoretical lexicography. In order to achieve this goal, a number of issues of paramount importance, which have always been in the focus of attention in Apresjan's publications, have to be discussed: (a) the notion of "naïve picture of the world", i.e. language-specific folk categorization encoded in the lexical and grammatical semantics of a particular language, as opposed to the supposedly universal and language-independent system of scientific concepts; (b) basic properties of the formal metalanguage of semantic desciption, its explanatory power and applicability in dictionary-making; and (c) representation of synonymy in a bilingual and a monolingual dictionary of synonyms designed within the framework of systematic lexicography. In addition, considerable attention has been given to two basic categories of systematic lexicography, "lexicographic portrait" and "lexicographic type", as well as the zonal structure of dictionary articles.
\end{abstract}

Keywords: BILINGUAL DICTIONARY, COMMONSENSE (EVERYDAY) KNOWLEDGE, DEFINITION, DICTIONARY OF SYNONYMS, EXPERT KNOWLEDGE, INTEGRATED LEXICOGRAPHIC DESCRIPTION, LEXICOGRAPHIC PORTRAIT, LEXICOGRAPHIC TYPE, METALANGUAGE, NAÏVE PICTURE OF THE WORLD, SCIENTIFIC PICTURE OF THE WORLD, SYNONYM SERIES, SYSTEMATIC LEXICOGRAPHY, TRANSLATION DICTIONARY, ZONAL STRUCTURE (OF A DICTIONARY ENTRY)

Opsomming: Jury Apresjan en die ontwikkeling van die semantiek en leksikografie. Die hoofdoel van hierdie artikel is om Juri Apresjan se invloed op die ontwikkeling van die linguistiese semantiek en teoretiese leksikografie uit te lig. Om hierdie doel te bereik, moet 'n aantal kwessies van die grootste belang wat nog altyd in die brandpunt van aandag in Apresjan se publikasies was, bespreek word: (a) die opvatting van 'n "naïewe beeld van die wêreld", d.w.s. taalspesifieke volkskategorisering wat in die leksikale en grammatikale semantiek van 'n bepaalde taal geënkodeer is, in teenstelling met die veronderstelde universele en taalonafhanklike stelsel wetenskaplike konsepte; (b) die basiese eienskappe van die formele metataal van semantiese beskrywing, die verklarende krag daarvan en die toepasbaarheid daarvan in woordeboeksamestelling; en (c) die aanbieding van sinonimiteit in 'n tweetalige en 'n eentalige sinoniemwoordeboek beplan binne die raamwerk van die sistematiese leksikografie. Hierbenewens is aansienlike aandag gegee aan twee basiese kategorieë van die sistematiese leksikografie, die "leksikografiese portret" en die "leksikografiese soort", asook die sonestruktuur van woordeboekartikels.

Sleutelwoorde: ALGEMENE (ALLEDAAGSE) KENNIS, DEFINISIE, GEÏNTEGREERDE LEKSIKOGRAFIESE BESKRYWING, LEKSIKOGRAFIESE PORTRET, LEKSIKOGRAFIESE SOORT, METATAAL, NAÏEWE BEELD VAN DIE WÊRELD, SINONIEMREEKS, SINONIEM- 
WOORDEBOEK, SISTEMATIESE LEKSIKOGRAFIE, SONESTRUKTUUR (VAN 'N WOORDEBOEKINSKRYWING), TWEETALIGE WOORDEBOEK, VAKKUNDIGE KENNIS, VERTALENDE WOORDEBOEK, WETENSKAPLIKE BEELD VAN DIE WÊRELD

\section{Introduction}

The book Systematic Lexicography published by Oxford University Press is a very impressive hardcover edition that comprises English translations of a number of Juri Apresjan's articles written over a timespan of 16 years. Moreover, as has been noted in the Translator's Note, these papers have been revised by the author specifically for the purposes of the publication at issue.

This selection of papers seems to cover all the peculiarities of the author's standpoint concerning theoretical semantics and lexicographic representation of linguistic phenomena. It is subdivided into two major parts titled Problems of Synonymy and Systematic Lexicography. The book is also provided with an Index of English Lexemes, an Index of Russian Lexemes, a Subject Index and an Index of Names. The Index of English words seems to be particularly important for the reader who is not engaged in the study of Russian or other Slavonic languages, but is an expert in the study of meaning or lexicography and may be, thus, interested in the author's treatment of common English lexical items.

The publication of a collection of Yuri Apresjan's articles in English may be called a very important event. ${ }^{1}$ For many linguists, who have not read his works in the original, Apresjan remains a mysterious figure. On the one hand, he is reputed to be an outstanding personality in the field of semantics and lexicography. For instance, in the Acknowledgements to Lingua Mentalis Anna Wierzbicka, expresses her gratitude to "Jura Apresjan", along with Igor Mel'čuk, for stimulating and challenging discussions that lasted for over 15 years (Wierzbicka 1980: xi). On the other hand, his publications available in English are scarce, to say the least. Hence, most of the international readership has been deprived of any first-hand information concerning his views on pertinent subjects. The volume under consideration, at least partly, compensates for this deficiency.

Though this article is intended to deal with the matters of lexicography, i.e. applied-linguistic description of the lexicon, we shall repeatedly (and unavoidably) touch upon theoretical-linguistic issues discussed in Apresjan's publications for a two-fold reason.

Firstly, Apresjan is both a theoretical semanticist and a practicing lexicographer, which is no exception in Eastern and Central Europe. It fact, high esteem of lexicographic practice has always been characteristic for this part of the world. Suffice it to say that a famous linguist, J. Baudouin de Courteney, once acted as the editor of the third edition of one of the largest Russian monolingual dictionaries originally compiled by V.I. Dal' (1903-1909) and implemented his theoretical beliefs in editorial practice. 
Secondly, Apresjan himself made a point of introducing his theoretical considerations if not immediately into lexicographic description, then at least into lexicographic theory. He writes the following in the Introduction to the volume under consideration (Apresjan 2000: XI):

Throughout the book I am concerned with two main issues - linguistic theory and lexicography. Until quite recently there has been a gap between the two. Moreover, in some quarters lexicography was looked down upon as a purely practical enterprise unworthy of scholarly interest. The present author is convinced, however, that sound lexicography can only be based on sound linguistic theory and that recent theoretical developments are of paramount importance for the practical skills of compiling a dictionary.

It should be noted in this connection that "sound linguistic theory" only is not sufficient for the production of an adequate reference work. In any lexicographic project, metalexicographic considerations, i.e. sound specifically lexicographic theory, are of no less importance. As I will try to show later, the latter, among other things, implies taking into account such lexicographic parameters of the reference work to be designed as its intended user, aims and objectives of the dictionary, a particular purpose the reference work is intended to serve, principles of lexicographic data selection, and a number of others.

To keep this article within manageable proportions, in the following we shall primarily occupy ourselves with a brief account of the issues of paramount importance that have always been the focus of attention in Apresjan's writings, namely: (a) the notion of "naïve picture of the world"; (b) metalanguage of semantic and/or lexicographic description; and (c) properties of synonyms and their representation within the framework of systematic lexicography.

Before addressing these matters we shall have to present a very brief, and by no means comprehensive, account of the theoretical background that has affected the interpretation of the aforementioned issues in the author's publications both translated for this volume and presented elsewhere.

\section{Theoretical Prerequisites}

Apresjan's writings can be properly understood and evaluated not only within the framework of developments in mainstream theoretical linguistics, but more specifically, against the background of the linguistic school that originated in the former Soviet Union on the basis of Russian linguistic tradition. It is obvious enough that we shall discuss only the most general tendencies and cannot possibly account for particular theoretical constructs, which, unavoidably, presupposes a certain degree of simplification.

Moreover, that linguistic tradition is not a sole property or a characteristic feature of Russian linguistic thought, but also developed in other Slavonic countries, for instance in Poland and Bulgaria, and a number of successor states 
to the former USSR.

Why Poland? For well-known historical reasons, cultural development of both countries has been related. Moreover, in connection with the matters under consideration, it should be specifically mentioned that Apresjan's beliefs were considerably influenced by what he referred to as "the Polish School of Semantics", particularly works of A. Bugusławski and A. Wierzbicka on metalanguage of semantic description (see bibliography in Apresjan 2000). ${ }^{2}$

It seems questionable that semantic investigation conducted in Poland is homogeneous enough to be regarded as one school, I would, personally, vote for at least several trends in semantic research, including quite a significant cognitively-oriented one (e.g., Kalisz 1981; Lewandowska-Tomaszczyk 1996; Krzeszowski 1997; to mention just a few). Nevertheless, it should be emphasized that a large number of linguists in both Russia and Poland, irrespective of their theoretical preferences, dedicated considerable attention to the study of culturally-induced elements of meaning and, even more specifically, cultural background encoded in, or underlying, the meanings and usage of lexical units (lexemes and phraseological units), particularly those belonging to the general vocabulary.

It is worthy of noting that thus acknowledged significance of widelyunderstood culture of a linguistic community, its shared assumptions about the world and society, ancient religious beliefs, even environmental conditions have motivated a number of lexicographic projects of a scholarly nature developed within the framework of academic lexicography. Their primary goal was to account for culturally-significant elements of word meanings. By way of example one may cite a short dictionary of traditional Russian poetic symbols (Ivanov et al. 1977) or a dictionary of folk stereotypes and symbols Stownik stereotypów i symboli ludowych (1999) developed under the general editorship of J. Bartmiński. The latter is, in fact, a large-scale on-going project whose major aim is formulated as "an attempt to reconstruct the traditional view of the world and man using methodology of ethnolinguistic and folklore research" (Bartmiński 1996: 9).

A point of crucial importance for the present discussion is the way the correlation between semantics and grammar was interpreted within the scope of linguistic exploration that was conducted in the former USSR. In this respect, the latter drastically differed from, for instance, the mainstream American linguistics that predominantly developed within the framework of form-oriented research as specified by L. Bloomfield and his followers, and may be said to have been, until recently, domineered by generative models of language.

A characteristic feature of generative models in various modifications is the assumption that syntax and semantics form two autonomous subsystems of language. Within this scientific paradigm the concept of linguistic semantics was virtually reduced to lexical semantics. Obviously enough, in this situation, the very term "lexical semantics" was tautological, since only lexical units were supposed to have meanings. 
Soviet linguistics rather adhered to more "traditional" postulates. One of these assumptions presupposed the existence of at least three major symbolic levels of the language structure, i.e. lexicon, morphology and syntax. In this respect, the trend of linguistic research under consideration is remindful of the cognitive linguistic approach to the study of language that originated fairly recently as a form of dissatisfaction with the drawbacks of generativism (cf. Langacker 1987: 2-3):

Grammar (or syntax) does not constitute an autonomous level of representation. Instead, grammar is symbolic in nature, consisting in the conventional symbolization of semantic structure. ... There is no meaningful distinction between grammar and lexicon. Lexicon, morphology and syntax form a continuum of symbolic structures, which differ along various parameters but can be divided into separate components only arbitrarily.

Thus, the trend of linguistic exploration that developed in the former USSR was based on the assumption that meaning is not the sole property of lexical items. Grammatical units (morphemes and syntactic structures) were regarded as kinds of linguistic signs, i.e. meaningful units. An immediate consequence of this standpoint is the implication that semantics as a linguistic discipline incorporates three subbranches: lexical semantics, morphological semantics and syntactic semantics.

For this very reason Apresjan's book titled Leksicheskaia semantika 'Lexical Semantics' came out in 1974 and was translated into Polish within six years of publication (Apresjan 1980), whereas its English counterpart, i.e. a monographic study with the same title, came out 12 years after (see Cruse 1986).

It is obvious enough that this theoretical-linguistic background justified Apresjan's conception of "integrated linguistic description" which is traceable to Shcherba's postulate that a dictionary and a grammar should produce a unified account covering the whole of language with no gaps (Shcherba 1940). This totally natural requirement has been repeated many times in its country of origin (e.g. see Seliverstova 1975). In fact, it could be reformulated elsewhere. Nevertheless, Apresjan's outstanding contribution to applied-linguistic investigation, among other things, encompasses an outline of such an integrated theory developed for the unified description of lexicon and grammatical system of a language, including: (a) rules of systematic representation of lexicographic information of this kind; (b) specification of corresponding formal devices of systematic lexicography; and (c) introduction of appropriate descriptive notions of crucial importance such as "lexicographic type" and "lexicographic portrait".

One of the principal categories in Apresjan's approach to the study of lexical (and grammatical) semantics is the notion of "naïve picture of the world", which appears indispensable in view of the aforementioned preoccupation with culture-specific elements of meaning. Simultaneously, this concept is assumed to be indispensable in lexicographic description, since it is stated that 
the primary task of systematic lexicography is to reflect the worldview in-built in a particular language (Apresjan 2000: 104). This descriptive concept will be our major concern in the next section.

\section{Naïve Picture of the World}

The cornerstone of Apresjan's approach to the study of meaning is based on Shcherba's seminal idea of the distinction between commonsense (everyday, folk) concepts and scientific notions (Shcherba 1940). The issue of framing of concepts and the structure of language, undoubtedly belongs to the key problems of linguistic semantics. A particular standpoint in this matter determines peculiarities of each trend in the study of meaning. Various interpretations of the correlation between commonsense knowledge and scientific knowledge structures as forms of categorization have been presented in the history of semantic description. For instance, Bloomfield maintained that commonsense notions in the definitions of lexical meanings should be substituted with corresponding scientific concepts. Thus, the lexeme salt should be defined as 'sodium chloride' or, alternatively, equated to the chemical formula of the substance designated by the lexical item in question (Bloomfield 1933).

Conversely, Shcherba's notion of commonplace concept as fundamentally different from the scientific concept may be said to be universally accepted in Russian linguistic tradition. By way of example he discussed the linguistic expression priamaia 'straight/direct (line)'. In geometry, a direct line may be specified as "the shortest distance between two points" (which is a scientific concept), whereas in everyday life we call "straight" or "direct" a line that deviates neither to the left, nor to the right (also neither upwards, nor downwards).

It is important to note that Shcherba introduced this distinction, which is, obviously, relevant for the theoretical study of meaning in linguistic semantics and lexicology, in a paper dedicated to general lexicographic theory. Since that time the notion of commonsense concept has been rediscovered and elaborated on by a number of semanticists and lexicographers. For instance, Hallig and Von Wartburg noted in the Introduction to their onomasiological (ideographic) dictionary that they aimed to account for "the worldview which is characteristic for an average intelligent speaker and is based on pre-scientific general concepts of which the language avails itself" (Hallig and Von Wartburg 1952: XIV). Thus, the lexicographers intended to reproduce the system of commonsense concepts in the classificatory scheme of their reference work. To what extent this goal was achieved in their dictionary and other lexicographic works of this kind is a different matter (for detailed analysis see Burkhanov 1999).

The concept of "naive picture of the world" was introduced into semantic and lexicographic description by Apresjan (1974 and other publications) to denote the aggregate of commonsense concepts underlying meanings of lexical items that form the general vocabulary. He has also noted that the idea of conceptual system forming a definite worldview is traceable to W. von Humboldt's 
writings and Sapir-Whorf hypothesis of linguistic relativity. Apresjan's major postulate is that the naïve picture of the world is, at least to some extent, language-specific, hence unique, whereas the scientific picture of the world was said to be universal, well-organized, logical, and language-independent.

According to Apresjan, the naïve picture of the world encoded in a particular language has been formed over centuries. It represents cultural and spiritual experience of a given linguistic community and includes naïve physics, naïve geometry, naïve psychology, naïve ethics, naïve physiology, etc. A point of primary importance is the assumption that these conceptual configurations are of a systematic nature (cf. Apresjan 2000: 104):

The naïve pictures of each of these areas are not chaotic but form definite systems and should therefore receive a homogeneous description in a dictionary. For this purpose, generally speaking, we should first reconstruct the corresponding fragment of the naïve picture of the world on the basis of lexical and grammatical meanings. In practice, however, in this case and others like it, the reconstruction and the (lexicographical) description go hand in hand and constantly provide each other with correctives.

The quotation above contains at least two statements that seem to be open to controversy. First, since each of the aforementioned semantic domains is assumed to be systematically organized, the naïve worldview should also form a homogeneous system opposed to the scientific worldview which is, by definition, even more systematic.

In connection with scientific categorization, it should be mentioned that there are various types of specialized knowledge which cannot possibly be referred to as scientific concepts or any system of these, for instance: categories of various branches of technology, sportive events, business, and other kinds of human activity which require expertise, professional training and specialist knowledge. These specific concepts are designated by lexical items of a terminological and semi-terminological character, but are beyond the scope of both commonsense knowledge and academic disciplines. The term "expert concept" seems to be a good candidate for the status of an overall category which, in addition to scientific concepts, includes the notions of the aforementioned heterogeneous human occupations. Thus, every scientific concept is an expert concept, but not all expert notions are scientific (see also appropriate entries in Burkhanov 1998).

Expert knowledge is not always universal; at least part of it may be culture-bound, i.e. induced by the peculiarities of cultural and/or historical development of the linguistic community. Every professional translator and/or expert in bilingual specialized lexicography has learned it by painful experience. Law, economics and politics may be cited as examples of typical culturedependent fields (e.g., see Reed 1993; Riggs 1993).

Bergenholtz and Tarp (1995: 60-61) claim that the distinction between culture-dependent and culture-independent subject fields proves usable, though 
sometimes it is not easy to draw a demarcation line between them and there are borderline cases that are difficult to be assigned to one class or the other.

It should be noted that the statement above includes a good deal of overgeneralization. In fact, we cannot specify, with any degree of certainty, which subject area can be unquestionably assigned to one class or the other. We cannot even say that all academic disciplines are culture-independent. My own experience of compiling a dictionary of semantic terminology in Russian (Burkhanov 1995) and a dictionary of lexicographic terminology in English (Burkhanov 1998) amply demonstrated frequent discrepancies between translationallyequivalent terminological units both in connotations and, more importantly, in the scope of conceptual content within different national specialist terminologies (for a detailed analysis see Burkhanov 2003: 126-135).

Even in the case of well-established academic disciplines the organizing assumption of uniformity of scientific description seems to be arguable. An overall picture of the world presupposes integration of worldviews presented in individual branches of science, such as physics, astronomy, chemistry, biology, history, sociology, and so on; not to mention interdisciplinary fields. It should be mentioned that the attempts at integration of several disciplines within the framework of a joint approach that may be considered successful, such as cognitive science, are few and far between. It seems to be extremely difficult, if not impossible, to design an overall scientific picture of the world at the present-day stage in the development of disciplinary and interdisciplinary studies.

In fact, the assumption that commonsense notions form a homogeneous system, i.e. a unified whole, also arouses suspicions. In principle, Shcherba's sharp opposition of commonsense (everyday) notions vs. scientific concepts appears to be too rigorist. It should be emphasized in this connection that types of categorization are too heterogeneous to be described in terms of a dichotomous division "commonsense" vs. "scientific" (cf. Lehrer 1992: 244). It seems more appealing to assume that numerous worldviews can, and do, co-exist in the semantics of a natural language and make their impact on the structure of semantic relations in the lexicon. The semantics of a particular language encompasses the representation of specific features of natural environment and ways of life, commonsense considerations, elements of conceptual systems of the past including those knowledge structures which originated as a by-product of mythological contemplation of the world, moral and customary beliefs of old times, etc. In view of these considerations it is difficult to expect that all those heterogeneous knowledge structures are amalgamated into a unified whole.

Another issue that seems to be controversial is the postulate that a theoretical-semantic model of the naïve picture of the world is directly applicable in lexicographic description, i.e. could be transferred wholesale from theoretical semantics into lexicographic practice. It seems more profitable to consider such a model as raw material of lexicographic investigation that has to be selected, 
prepared, and only afterwards presented depending on the dictionary parameters that have been chosen for a given lexicographic project.

In addition, a model of an overall naïve picture of the world presented by a semanticist may be found inconsistent or not comprehensive enough from the viewpoint of lexicographic description. By way of example, let us consider Apresjan's interpretation of the notion of man in the naïve picture of the world as manifested in the Russian language. In particular, Apresjan (2000: 105) noted that man performs three basic types of action: physical actions, intellectual actions, and speech acts. These types of action both in theoretical considerations and in actual semantic descriptions are considered to be sufficient for an adequate account of the variety of activities and acts performed by humans.

It seems reasonable to add to the aforementioned three types of action at least one more, namely: social actions. It will be fair to say that it is not only Apresjan's fault, other experts in theoretical semantics also failed to specify this type of action. The actions under consideration are designated by both appropriate action verbs as well as adjectival and nominal lexemes. The necessity to introduce this descriptive category becomes evident in the course of semantic analysis of the following lexical items, for instance: disinherit, i.e. 'to undertake certain social actions so that somebody, especially one's son or daughter, will not receive one's money and property after one's death' and influential as "having great social power", where power means "ability to perform actions of certain type" and social power stands for "possession of control, authority or influence over others", cf.: John was disinherited by his father or He is a very influential politician. These lexical items seem to warrant semantic description of the following kind:

$$
\begin{aligned}
& \text { influential }=\text { HAVE + ABILITY [ perform social actions] + > NORM (where } \\
& \text { the sign }>\text { stands for "more than"); } \\
& \text { disinherit }=\text { CAUSE + STOP + HAVE [right (BEGIN + HAVE \{money or } \\
& \text { property\}] + TEMPORAL SPECIFICATION [after one's death]. }
\end{aligned}
$$

Social actions often incorporate, or are manifested by, physical and/or verbal actions. Nevertheless, basic conceptual elements of the former stand for primarily socially and/or culturally significant acts or activities, cf.: marry (transitive) "to establish a social relationship [marriage] between (at least prototypically nowadays) a man and a woman". In view of Apresjan's principle of uniform systematic representation of relevant semantic information, social actions seem to require specification as a lexicographic type.

It can be argued that in some cases it is very difficult, if not impossible, to draw a sharp demarcation line between physical actions on the one hand and social actions on the other. Nevertheless, the same can be said about other postulated types of action, cf.: discuss which is usually interpreted as a speech act verb, though its meaning also encompasses mental activity.

Probably the failure to pay sufficient attention to such cases can be attrib- 
uted to the attempt to specify lexical meanings in terms of definitions written in a formal metalanguage. As will be shown in the next section, the latter implies the minimum definition requirement as well as simplification of semantic relations.

\section{Metalanguage of Semantic and / or Lexicographic Description}

For years Apresjan was an ardent adherent of the idea that dictionary definitions should be formulated in a special formal metalanguage of semantic description developed in the publications of the Moscow Semantic School (e.g., see Zholkowsky 1964; Mel'čuk 1974; Apresjan 1974; Mel'čuk 1982). Summarizing the achievements of theoretical semantics and the first attempts at lexicographic descriptions in terms of metalanguage, he suggested the following requirements for its basic components: vocabulary and syntax (Apresjan 1974: 70-106).

As for syntax, the major requirement as formulated by the adherents of the Moscow Semantic School is to ensure nonambiguous notation of meaning configurations. The syntax of semantic graphs and dependency trees was declared the ideal solution, whereas the use of a simplified version of the syntax of a natural language was regarded as no more than a palliative (e.g. see Mel'čuk 1974: 53; Apresjan 1974: 77-79; Apresjan 2000: 216).

The core of the vocabulary of the metalanguage was presumed to be composed of semantic primitives. Each vocabulary unit should designate only one, preferably elementary, meaning, whereas each elementary meaning should be designated by one and only one word. Hence, the major requirement presupposes one-to-one correspondence between meaning and form of the word. Thus, vocabulary units of the metalanguage, unlike lexical items of natural languages, should be devoid of polysemy and homonymy. Moreover, the number of elementary meanings should be limited (minimum definition requirement), though sufficient to account for the linguistic facts under consideration (exhaustive definition requirement).

The theoretical metalanguage is designed using "artificial words" or "word-constructs", i.e. lexemes of the natural language with stipulated meanings or specifically coined words with stipulated meanings. Some of them were borrowed from natural sciences, mathematics and logic, cf.: mnozhestvo 'set' (in the mathematical sense), sila 'force, power', funktsia 'function'; others were invented, cf.: kauzirovat' 'to cause', potok faktov 'current of facts'; and others, though they are general vocabulary units, are used in restricted sense, cf.: veshch 'thing', kolichestvo 'quantity', norma 'norm'.

The choice of pre-existing lexical items and coinage of new ones to be included in the vocabulary of the semantic metalanguage was motivated by the properties of the Russian language. The terminological unit mnozhestvo was formed on the basis of the literal meaning of the word 'a very large number of', cf.: mnozhestvo faktov 'a large number of facts', mnozhestvo sluchaev 'a large num- 
ber of cases', etc. In the terminological sense it stands for a collection of objects or elements classed together on the basis of a common property. It should be mentioned that mnozhestvo is a better solution as compared, for instance, to its English translation equivalent for a two-fold reason. First, the meaning of the former is motivated and, hence, easier to understand, since it is related to a high-frequency general vocabulary lexical item mnogo 'many, much'. Simultaneously, the noun mnozhestvo, unlike mnogo, is nonambiguous, since it refers to collections of countable objects. The English word set is too polysemous; its appropriate interpretation in the sense under consideration is context-bound. Moreover, in everyday language set often designates a collection of artefacts that are specifically designed to be used together or for a particular purpose, cf.: a set of china or a set of carving knives. The latter sense could have unduly limited the scope of meaning representation.

Thus, the choice of a lexical item to be included in the metalanguage was very apt in the case of mnozhestvo. As for the other word, sila, certain difficulties may arise, since it designates both the ability to perform actions, particularly physical strength, and a property of an action, i.e. the energy exerted. It is not by chance that the lexical unit in question is often translated as power or force into English. This kind of polysemy characteristic for a natural language may lead to misinterpretation either on the part of the researcher who uses this word in a stipulated meaning in the metalanguage or on the part of the dictionary user. Of course, it may be argued that both the researcher and the dictionary user know that the word sila is supposed to be used in semantic descriptions in the sense that is closer to the scientific usage in physics. Nevertheless, a possibility of unwanted misinterpretation still exists.

Explications of lexical meanings in a formalized metalanguage of description were presented in a number of lexicographic projects (Mel'čuk and Zholkovsky 1984; Mel'čuk et al. 1984, 1988, 1992; Wierzbicka 1987). Nevertheless, all of them were of a rather experimental nature and developed within the framework of academic lexicography. Irrespective of the fact whether it was acknowledged by the lexicographers or not, these works of reference displaying outstanding scholarly values are primarily meant for a professional linguist, not a lay dictionary user. So far they have been no competition for monolingual dictionaries providing definitions in a natural language, particularly with respect to user-friendliness.

It is obvious enough that semantic descriptions in a formal metalanguage are quite applicable in the case of computational lexicography, information retrieval systems and machine translation. Suffice it to say that Mel'čuk continues to investigate the applicability of lexical functions for the purposes of text analysis and text generation with a group of other experts in the field (e.g. see Wanner 1996).

In 1994 Apresjan published an article in which he overtly specified a different conception of metalanguage of lexicographic description. First, by way of justification a distinction of semantic representation into surface and deep 
sublevels, which was proposed in an earlier article, was featured. Among other things, he claimed that the idioethnic semantics of a particular language should be handled by the surface-semantic component of the model. In order to produce a comprehensive account of semantic facts it was proposed "to use not an artificial language, but a somewhat simplified and unified sublanguage of the object language", i.e. lexical items and syntactic structures of the language under consideration (Apresjan 2000: 217).

Further on the requirements imposed on thus understood metalanguage of lexicographic description were formulated: (a) the lexical stock should be limited; (b) the vocabulary of the metalanguage should be unified to eliminate synonymy and homonymy; etc. It is evident enough that these requirements are not too much different from those specified for defining vocabulary in what Apresjan refers to as "traditional lexicography" (cf. Svensén 1993: 135-138).

It is important to emphasize that the statement above meant an actual resignation from the principle of obligatory definitions based on metalanguage of semantic description. In fact, it was the major issue of controversy between the Moscow Semantic School (Mel'čuk, Zholkovsky, Apresjan and others) and the leading figures of contemporary linguistics in the USSR. The former insisted that adequate lexicographic works of reference could be produced only on the basis of a formal metalanguage, whereas the latter tried to prove the advantages of conventional lexicographic representation. This conflict resulted in publications intended to undermine the academic achievements of "the rebellious semanticists" and sometimes went far beyond the scope of academic discussions (e.g., see Kotelova 1975).

The evolution of Apresjan's views concerning the subject is the telltale evidence that the choice of a particular type of definition for a given lexicographic project depends on a number of considerations, some of them of a practical nature. In fact, one may say that the question of selection of defining techniques cannot be reduced to a straightforward, simplistic answer: "Which one is better?" Probably it should be reformulated as follows: "Which one is better for a particular type of dictionary to account for a particular class of linguistic facts?"

The answer to this query always implies satisfactory specification of a dictionary type in terms of a number of parameters of the reference work to be designed: (a) the intended dictionary user (age group, prior knowledge of the subject in the case of LSP reference works, level of proficiency in the foreign or second language in the case of pedagogical lexicography, etc.); (b) aims and objectives of the reference work (reference only, instruction, professional translation, etc.); purpose (production or text comprehension); (c) lexicographic material to be presented in it; etc. ${ }^{4}$

Instead of a rigid requirement to use metalanguage in dictionary definitions it seems more profitable to assume a more flexible approach which allows for the selection of not only defining techniques, but also the most efficient technique of lexicographic presentation (in reality their combinations) inclusive 
of graphic representation, exemplification, usage and grammatical labels, crossreferencing, etc. In fact, the adequate description of these tools of lexicographic representation and their applicability remains a priority of metalexicography. Such a description should specify advantages and disadvantages of each and every technique so that practicing lexicographers could select appropriate combinations of these techniques to design the most efficient form of lexicographic presentation for a given reference work.

\section{Synonymy and its Representation in Systematic Lexicography}

Apresjan's beliefs concerning lexicographic description have been put forward under the umbrella term "systematic lexicography". He formulated four major principles of systematic lexicography as follows: (a) the dictionary should be designed to accommodate the needs of active production, i.e. it should be oriented towards use in speech; (b) the dictionary should be integrated, i.e. lexicographic description should, in particular, take account of the differing grammatical conditions of use; (c) the dictionary should be systematic in the sense of taking account of the different lexicographic types to which the lexeme under consideration belongs; and (d) the dictionary should reflect the naïve picture of the world.

Thus, a basic tenet of systematic lexicography is that the lexicon should be described in terms of "lexicographic types", i.e. groups of lexemes with a shared property or properties (not necessarily semantic), subject to the same linguistic rules, which warrants a uniform description in the dictionary. Apresjan (2000: 102) provided the following definition of the notion under consideration:

The central concept of systematic lexicography is that of the lexicographic type, a group of lexemes with at least one common property (semantic, pragmatic, communicative, syntactic, combinatorial, morphological, prosodic, etc.), to which the same rules of linguistic description (of 'grammar' in the broad sense) refer and which therefore requires a homogenous description in a dictionary.

Lexicography traditionally dealt with lexical-semantic (and partly grammatical) properties of lexical items. In the case of some languages which, like English, are characterized by a noticeable discrepancy between the orthographic and phonological properties of lexemes, transcriptions are provided intended to account for segmental phonemes composing appropriate phonological words and word stress. In some dictionaries combinatorial features of lexical items (particularly lexical-semantic valence) are described. Nevertheless, it will be fair to say that lexicographic description has been centred on the word and accounted for its properties only.

In view of the considerations above, Apresjan's intent to account for prosody appears innovative and extremely promising, particularly in the case of intonation which is usually neglected in both dictionaries and grammars. For instance, initial position is normal for so-called "sentence adverbs" in English: 
naturally, geographically, etc. They are usually characterized by the fall-rise intonation pattern and separated from the rest of the utterance by a pause signifying the syntagm boundary in the spoken mode of communication, whereas in the written mode this boundary is represented by a comma.

This group of adverbs qualifies for the status of a lexicographic type by virtue of at least three features in common: their syntactic function as well as phonological and orthographic properties. It is only reasonable to assume that these aspects of their usage should be accounted for in reference works, at least in some dictionaries, usage guides, and reference grammars. Again, the question of intended user immediately arises in this connection. Providing suprasegmental features of the aforementioned type seems to be obligatory in learner-oriented reference materials. From this viewpoint, it is natural to represent lexicographic information of the kind in the nonnative speaker-learner's production dictionary (and/or grammar book), whereas this matter should be reconsidered in the case of a general-purpose dictionary designed for the native speaker-user.

It should be noted that Apresjan's description of verbs of perception in Russian in terms of two main participants, the one who perceives and the second the thing perceived, may be considered as a masterpiece of semantic analysis. No less imposing are "lexicographic portraits" of the verbs shchitat' 'consider', znat' 'know', vyiti 'come out' and a number of other lexical items, which are also represented in the book under consideration. Before we proceed, it is necessary to discuss the notion of lexicographic portrayal.

The term "portrait" was introduced into descriptive semantic research by A. Zholkovsky (1964). For him, a portrait should incorporate an exhaustive description of word meaning attained by using it in the broadest possible range of contexts and experimenting with its applicability for the description of the broadest range of situations. Thus, the notion of portrayal was primarily limited to the specification of conceptual content and reference of a lexical item obtained, and/or verified, by linguistic experiment. Apresjan suggested a broader interpretation of the scope of this concept within the framework of integrated description of a language (cf. Apresjan 2000: xvi):

A lexicographic portrait is an exhaustive account of all the linguistically relevant properties of a lexeme, with particular emphasis on the semantic motivation of its formal properties. A certain property is considered to be linguistically relevant if there is a rule of grammar or some other sufficiently general rule (semantic rules included) that access this property.

This term based on metaphorical extension was intended to emphasize that a dictionary entry should store lexicographic data hitherto not included in reference works and should considerably expand the amount of lexicographic information that dictionaries traditionally contain. In addition to the aforementioned prosodic features, one may note particular interest to lexical co-occurrence, i.e. combinability of lexical items. Apresjan (2000: 232) mentions that 
the latter encompasses, in addition to lexical-semantic constraints, "prosodic, morphological, pragmatic, communicative and syntactic co-occurrence".

It should be mentioned in this connection that Apresjan developed his own interpretation of the pragmatics of a natural language. It has to be featured here because otherwise it is difficult to understand how to distinguish pragmatic properties of a lexeme from its communicative properties on the one hand, and its semantic ones on the other, particularly in view of the requirement that each of these types of lexicographic information at least was supposed to be represented in a different part of the dictionary entry.

In an article specifically dedicated to the issues of representing pragmatic information in a dictionary (Apresjan 1988) defines pragmatics as the expression of the speaker's attitude to reality, the message and/or the interlocutor, which is encoded in a linguistic sign, i.e. a lexical item, a morpheme or a syntactic structure. Moreover, the notion of pragmatic information in his interpretation sometimes includes lexical connotations and associations as opposed to components of meaning in the strict sense, e.g. connotation of monotony in the verb pilit' 'saw' which is characterized by a metaphorical extension 'nag', of abruptness in rubit' 'chop', and of speed in streliat' 'shoot'. Simultaneously, he also uses the terms "pragmatic information" or "pragmatic features" in the sense which does not deviate much from their generally-accepted usage; cf.: capacity for performative use or inadmissibility in reported speech and nontrivial illocutionary functions of a lexeme (e.g., see Apresjan 2000: 264). Nevertheless, in all these cases and similar ones, pragmatic information is regarded as a property of linguistic signs as units of a language-system; hence it requires uniform lexicographic presentation.

Thus, the notion of lexicographic type was introduced to emphasize the tendency to standardization of lexicographic presentation of shared properties, i.e. unification, whereas that of lexicographic portrait accounts for lexicographic presentation of what distinguishes lexical items, i.e. individualization.

The foregoing considerations enabled Apresjan to highlight basic principles of lexicographic description of synonymy in systematic lexicography, particularly requirements for a dictionary of synonyms. It will be fair to say that Apresjan's greatest contribution to metalexicography is the specification of basic principles of compiling a bilingual and a monolingual dictionary of synonyms.

In connection with bilingual lexicography, it is important to note that Shcherba in the aforementioned article made a tentative suggestion that a pedagogical dictionary should furnish not so much the translation equivalents of foreign language lexical items, but also and more importantly, detailed definitions in the learner's native language. From this it follows that a bilingual dictionary may be specifically designed either to serve the purposes of professional translation or to accommodate the needs of a nonnative language learner.

These two different purposes warrant different types of definitions (for a detailed analysis see Burkhanov 1999: 235-254; and Burkhanov 2003: 193-200). 
Obviously enough, this approach opens up new perspectives for the development of bilingual lexicography which, for many experts in the field of lexicographic theory, still remains a synonym of translation lexicography (cf. Zgusta 1984). Moreover, with the further development of pedagogical lexicography it is reasonable to expect that more and more bilingual reference works will be intended to explicate meaning and usage of lexical items of the object language in the learner's native language. In this case, the latter will be used as a metalanguage of lexicographic description.

A successful attempt to implement Shcherba's ideas with respect to bilingual lexicography has been undertaken by a group of lexicographers under the leadership of Apresjan in the English-Russian dictionary of synonyms (Apresjan et al. 1979). Each entry (or rather dictionary article) of the reference work at issue, contains a detailed specification of the synonym series, i.e. the ordered list of synonyms, and consists of the following zones:

(1) entry head comprising a list of synonyms starting with the lexical item with the most general meaning; (2) explanatory definition in Russian intended to specify the elements of meaning that are shared by all the synonyms, primarily the appropriate naïve concept and the evaluative component of meaning; (3) translation equivalents intended to simplify understanding explications and, at least partly, to compare the corresponding synonym series in English and Russian; (4) detailed explications of the synonyms in a given series with a particular emphasis on meaning discrimination, i.e. specification of their similarities and differences; (5) notes that account for those meanings of words making up the series which are close to the meanings under consideration as well as comments concerning figurative senses of those lexical units; (6) syntactic information; (7) co-occurrence constraints; and (8) illustrative examples.

As any other lexicographic publication, the dictionary under consideration is not free from drawbacks. Firstly, only one-word lexical items are included into synonym series; synonymous multiple-word lexical items, i.e. phraseological units, are beyond the scope of the dictionary. Secondly, synonyms are presented solely in a graphic form, whereas pronunciations of the corresponding phonological words are not provided, not to mention prosodic properties. Thirdly, the dictionary furnishes detailed specifications of synonyms on the scale that is unprecedented in bilingual lexicography, but only 350 synonym series are featured in it. It is not by chance that Apresjan himself called the dictionary "experimental". Nevertheless, this lexicographic project is, undoubtedly, an important milestone in the development of contemporary lexicography.

As for a monolingual dictionary of synonyms, Apresjan (2000: 55-100) suggested the following zonal structure of dictionary articles: (1) the zone of heading which comprises the dominant, i.e. a synonym with the most general 
meaning, stylistic labels and grammatical notes, semantic groups within the series and their explication; (2) the zone of meaning specification that includes a synopsis (a short guide to the entry), similarities and differences in meaning between synonyms, etc.; (3) the form zone that accounts for the formal properties of usage; (4) the syntax zone; (5) the co-occurrence zone specifying combinatorial properties of the synonyms belonging to a series; (6) the illustration zone; and (7) the auxiliary zones. It is interesting to note that Apresjan decided to include phraseological synonyms into lexicographic material collected and analyzed for Novyi ob'iasnitel'nyi slovar' sinonimov russkogo iazyka 'New Explanatory Dictionary of Russian Synonyms' (Apresjan et al. 1997).

Hopefully the foregoing considerations have persuaded the reader that Juri Apresjan's book Systematic Lexicography is a very interesting and highly recommendable publication for both a practicing lexicographer and an expert in lexicographic theory. Not the least profit is to be gained by a theoretical semanticist who has never been exposed to Apresjan's stimulating and innovative ideas.

It should be specifically mentioned that a considerable part of the impact of this publication arises due to Kevin Windle's excellent translation. Paraphrasing a popular definition of translation, it can be said that he successfully coped with the extremely difficult task of "negotiating meaning in a different academic background".

\section{Notes}

1. For me, a linguist whose academic career began in the former USSR, Apresjan's book Leksicheskaia semantika originally published in 1974 was the first introduction to the works of A. Wierzbicka, Ch. Fillmore, G. Lakoff, and other internationally renowned experts in the study of meaning, not to mention that it was rightly regarded as a leading monographic study in semantic analysis. I am indebted to the Editor of Lexikos for giving me an opportunity to reconsider Apresjan's impact on the theoretical and applied study of language.

2. To keep the bibliography of the present article to the minimum and to make it easier for the prospective reader to locate the required information in the English translation, references to Apresjan's articles included in the volume under consideration will be made not to the original, but to the appropriate pages of the publication in question.

3. It is interesting to note that cognitive semanticists interpret the distinction between these two senses in terms of the distinction between primary and secondary domains. Salt in everyday sense is primarily associated with the domain of food, whereas the terminological unit sodium chloride which has the same reference, is understood against the domain of chemical composition (Langacker 1987: 165; Taylor 1989: 85-86). Thus, the standpoint of cognitive semantics and that of Russian linguistic thought are similar in this respect, though they are formulated within two different scientific paradigms.

4. More information concerning dictionary typology on the basis of distinctive features or lexicographic parameters can be found in Hartmann and James 1998: 147-148; Burkhanov 1998: 68-72; and other sources. 


\section{Bibliography}

Apresjan, J.D. 1974. Leksicheskaia semantika: sinonimicheskie sredstva iazyka. Moscow: Nauka.

Apresjan, J.D. 1980. Semantyka leksykalna. Synonimiczne środki języka. Translated by Z. Kozlołowska and A. Markowski. Wrocław: Ossolineum.

Apresjan, J.D. 1988. Pragmaticheskaia informatsiia dlia tolkovogo slovaria. Pragmatika $i$ problemy intensional'nosti: Sbornik nauchnykh trudov: 7-44. Moscow.

Apresjan, J. 2000. Systematic Lexicography. Translated by Kevin Windle. Oxford/New York: Oxford University Press.

Bartmiński, J. 1996. O "Słowniku stereotypów I symboli ludowych". Bartmiński, J. (Ed.). 1996. Słownik srereotypów i symboli ludowych. Volume 1. Kosmos: ziemia, woda, podziemie: 9-34. Lublin: UMCS Press.

Bergenholz, H. and S. Tarp (Eds.). 1995. Manual of Specialised Lexicography. Amsterdam/Philadelphia: John Benjamins.

Bloomfield, L. 1933. Language. New York: Holt and Co.

Burkhanov, I. 1995. Uchebnyi slovar' sistemy poniatii lingvisticheskoi semantiki. Rzeszów: University Press.

Burkhanov, I. 1998. Lexicography: A Dictionary of Basic Terminology. Rzeszów: University Press.

Burkhanov, I. 1999. Linguistic Foundations of Ideography: Semantic Analysis and Ideographic Dictionaries. Rzeszów: University Press.

Burkhanov, I. 2003. Translation: Theoretical Prerequisites. Rzeszów: University Press.

Cruse, D.A. 1986. Lexical Semantics. Cambridge: University Press.

Hartmann, R.R.K. and G. James. 1998. Dictionary of Lexicography. London/New York: Routledge.

Kalisz, R. 1981. The Pragmatics, Semantics and Syntax of the English Sentences with that Complements and the Polish Sentences with że Complements. Gdańsk: University Press.

Kotelova, N.Z. 1975. Znachenie slova i iego sochetaemost' ( $k$ formalizacii $v$ iazykoznanii). Leningrad: Nauka.

Krzeszowski, T.P. 1997. Angels and Devils in Hell. Warsaw: Energeia.

Langacker, R. 1987. Foundations of Cognitive Grammar. Volume 1. Theoretical Prerequisites. Stanford: University Press.

Lehrer, A. 1992. A Theory of Vocabulary Structure: Retrospectives and Prospectives. Pütz, Martin (Ed.). Thirty Years of Linguistic Evolution: 243-256. Amsterdam/Philadelphia: John Benjamins.

Lewandowska-Tomaszczyk, B. 1996. Depth of Negation: A Cognitive Semantic Study. Łódź: University Press.

Mel'čuk, I.A. 1974. Opyt teorii lingvisticheskikh modelei "Smysl $\Leftrightarrow$ Tekst". Moscow: Nauka.

Mel'čuk, I.A. 1982. Lexical Functions in Lexicographic Description. Proceedings of the VIIIth Annual Meeting of the Berkeley Linguistic Society: 427-444. Berkeley: University Press.

Reed, D. 1993. Some Terminological Problems of Translating Common Law Concepts from English to French. Sonneveld, H.B. and K.L. Loening (Eds.): 79-86.

Riggs, F. 1993. Social Science Terminology: Basic Problems and Proposed Solutions. Sonneveld, H.B. and K.L. Loening (Eds.): 195-222.

Seliverstova, O.N. 1975. Komponentnyi analiz mnogoznachnykh slov. Moscow: Nauka.

Shcherba, L.V. 1940. Opyt obshchei teorii leksikografii. Izvestiia Akademii Nauk SSSP (otdelenie literatury i iazyka) 3: 89-117. 
Sonneveld, H.B. and K.L. Loening (Eds.). 1993. Terminology: Applications in Interdisciplinary Communication. Amsterdam/Philadelphia: John Benjamins.

Svensén, B. 1993. Practical Lexicography: Principles and Methods of Dictionary-Making. Transl. by J. Sykes and K. Schofield. Oxford/New York: Oxford University Press.

Taylor, J. 1989. Linguistic Categorization: Prototypes in Linguistic Theory. Oxford: Clarendon Press.

Wanner, L. (Ed.). 1996. Lexical Functions in Lexicography and Natural Language Processing. Amsterdam/Philadelphia: John Benjamins.

Wierzbicka, A. 1980. Lingua Mentalis: The Semantics of Natural Language. Sydney/New York: Academic Press.

Zgusta, L. 1984. Translational Equivalence and the Bilingual Dictionary. Hartmann, R.R.K. (Ed.). LEXeter '83 Proceedings: 147-154. Tübingen: Niemeyer.

Zholkovsky, A.K. 1964. Predislovie. Mashinnyi perevod i prikladnaia lingvistika 8: 3-16.

\section{Lexicographic Publications}

Apresjan, J.D., O.Iu. Boguslavskaia, I.B. Levontina, E.V. Urynson, M.Ia. Glovinskaia and T.V. Krylova. 1997. Novyi ob'iasnitel'nyi slovar' sinonimov russkogo iazyka. Pervyi vypousk. Moscow.

Apresjan, J.D., V.V. Botiakova, T.E. Latysheva, M.A. Mosiagina, I.V. Polik, V.I. Rakitina, A.I. Rozenman and E.E. Sretenskaia. 1979. Anglo-russkii sinonimicheskii slovar'. Moscow: Russkii iazyk.

Bartmiński, J. (Ed.). 1996; 1999. Stownik srereotypów i symboli ludowych. Vol. 1. Kosmos: ziemia, woda, podziemie. Lublin: UMCS Press.

Dal', V.I. 1863-1866. Tolkovyii slovar' zhivogo velikorusskogo iazyka. Third Edition. Edited by I.A. Baudouin de Courteney. 4 volumes. Saint-Petersburg, 1903-1909.

Hallig, R. and W. von Wartburg. 1952. Begriffssystem als Grundlage für Lexikografie. Versuch eines Ordnungsschemas. Berlin: Akademie Verlag.

Ivanov, V.V., V.M. Pan'kin, A.V. Filippov and H.M. Shansky. 1977. Kratkii slovar' traditsionnykh simvolov russkoi poezii. Russkii iazyk. 4-5.

Mel'čuk, I.A. and A.K. Zholkovsky. 1984. Tolkovo-kombinatornyi slovar' sovremennogo russkogo iazyka. Sonderband 14. Vienna: Wiener Slawistischer Almanach.

Mel'čuk, I.A., N. Arbatchewsky-Jumarie, L. Elnitsky, L. Iordanskaja and A. Lessard. 1984. Dictionnaire explicatif et combinatoire $d u$ français contemporain. Volume I. Montréal: Presses de l'Université de Montréal.

Mel'čuk, I.A., N. Arbatchewsky-Jumarie, L. Dagenais, L. Elnitsky, L. Iordanskaja, M.-N. Lefebvre and S. Mantha. 1988. Dictionnaire explicatif et combinatoire du français contemporain. Volume II. Montréal: Presses de l'Université de Montréal.

Mel'čuk, I.A., N. Arbatchewsky-Jumarie, L. Iordanskaja and S. Mantha. 1992. Dictionnaire explikatif et combinatoire du français contemporain. Volume III. Montréal: Presses de l'Université de Montréal.

Wierzbicka, A. 1987. English Speech Acts Verbs: A Semantic Dictionary. London/Port Worth/Philadelphia: Harcourt Brace Jovanovich. 